\title{
Environmental Life Cycle Costing (ELCC) in the aspect of cost management in the company
}

\author{
Michał Biernacki*
}

\begin{abstract}
Purpose - from a methodological point of view, life cycle costing (LCC) is well developed with respect to conventional costs. This paper aims at presenting the concept idea of Environmental Life Cycle Costing. It expresses the continuous study progress in environmental protection as well as accounting. Ecological and balanced understanding have become constituent of present applied management method. Owing to such an approach, one elicits informational base of cost and revenue connected with the product impact on natural and civic environment. Total cost of ELCC becomes supplement of traditional understanding of Environmental Life Cycle Costing. Moreover total cost of ELCC improves LCA technique. It is defined as the total cost of product's life cycle together with environmental costs. Design/Methodology/Approach - the article begins by looking at the driving forces for introducing life cycle costing, environmental life cycle costing, continues by identifying external and internal environmental cost issues, and concludes with supplemental conception. Findings - the literature on the subject is so limited. There is not sufficient to aid in estimation of environmental costs and benefits for a company. This paper may help in structuring the task of using ELCCA and LCC. Originality/Value - there has been increased interest recently in the presenting ELCC. This paper contributes with new outlooks and structures for that work. It offers theoretical and practical help to managers within companies.
\end{abstract}

Keywords: cost accounting, LCC, LCA, ELCC, environmental management

\section{Introduction}

The main assumption of ecological Life Cycle Assessment (LCA) is to fully and meticulously identify the influence of the product on the natural environment during its life cycle. Such conceptualization causes situation when one does not take into consideration economical and civic matters. Thus, it significantly reduces the possibility of LCA technique usage in decision making process. There is no cost analysis as well as so called efficiency calculus in this classic understanding. LCA should be supplemented with cost analysis as a part of so called Environmental Life Cycle Costing (ELCC). Such process allows to determine the relationship between the potential product's influence on the environment and related costs. The article's aim is to present ELCC calculus as a development conception of Life Cycle Costing on the base of previous experiments, international studies, and worldwide literature analysis.

\footnotetext{
* dr inż. Michał Biernacki, Uniwersytet Ekonomiczny we Wrocławiu, ul. Komandorska 118/120, 53-345 Wrocław, e-mail: michal.biernacki@ue.wroc.pl.
} 


\section{Definitional conceptualization of Life Cycle Costing - LCC}

Life Cycle Costing (LCC) in the literature is classified as one of the modern cost calculus model, nonetheless there is no consistent definition of the mentioned idea.

Defining Life Cycle Costing one should first mention D. Haworth's explanation, who stated that LCC is the process of gathering information about costs concerning specific decision during the life cycle of such a decision (Haworth 1975: 13-20).

S. Ansami and J. Bell mentioned that Life Cycle Costing of a service is summed costs of activities from the moment when the idea appeared until the moment the product has been retracted from the market. The authors notice that the life cycle does not end at the moment of selling the good, yet companies can offer service and post-sale service (Ansami 1997).

D.G. Woodward states that Life Cycle Cost of an item is the sum of all funds expended in support of the item from its conception and fabrication through its operation to the end of its useful life (Woodward 1997: 336).

American Institute of Logistical Management defines LCC as a sum of costs of possessing an item, together with costs of purchase or production, using an item in business activity, repairs, staff training and costs of reducing of an item (Informacja zarzadcza... 2003: 202).

H.A. Baussabaine and R.J. Kirkham enumerate so called Whole Life Cycle Costing (WLCC) which, apart from sum of costs directly connected with the product, includes costs of capital, "risk costs", costs connected with environment protection with emphasis on the problem of choosing appropriate estimating methods (Baussabaine, Kirkham 2004: 7-9).

In Polish literature of management accounting, Life Cycle Costing is described as a model reflecting product's class ability to generate income of capital and defining forecasting costs connected with mentioned income (Nowak 2004: 156-157). The word "product” is understood as a class of product, not a single crafted article, or service.

Concerning LCC, B.S. Dhillon enumerates three main cost groups. Costs of research and development incurred during the pre-market phase, production cost, selling cost and other incurred cost during market phase, as well as cost of ending the production or/and providing service at the last phase of life (Dhillon 1989: 46-47). Total LCC can be represented in the following way:

$$
K_{L C C}=K_{P}+K_{B}+K_{P R}+K_{S}+K_{I}+K_{L},
$$

where:

$\mathrm{K}_{\mathrm{LCC}}$ - Life Cycle Costing,

$\mathrm{K}_{\mathrm{P}}$ - designing and planning cost,

$\mathrm{K}_{\mathrm{B}}$ - research and development cost,

$\mathrm{K}_{\mathrm{PR}}$ - production/service cost,

$\mathrm{K}_{\mathrm{S}}$ - selling cost,

$\mathrm{K}_{\mathrm{I}}-$ other incurred costs during market phase,

$\mathrm{K}_{\mathrm{L}}$ - termination and disposal cost (Dhillon 1989: 48).

In the practice of Japanese companies, one can meet an approach to LCC, when the life of a product does not end at the moment of sale, yet when a final client desists to use a product. There are three main phases in the life cycle:

- designing phase, 
- production phase,

- post-sell phase (Rachunek kosztów... 2003: 374).

Translating it into Life Cycle Cost, the area of born costs are composed of manufacturer cost and cost born by end-user during the time of product usage. Such an approach is consensual with Japanese philosophy of management process quality that enables companies to direct them straight upon the market and achieving success in near future (Rachunek kosztów... 2003: 374).

Product life-cycle management together with target costing form are called as the global costing system, which is compiled after defining and accepting the concept of a new product. In its assumption, forecasting sale cost at different markets, different variations of a product and assumed places of its production in future, as well as forecasting financial income, born cost and revenue are took into consideration. At the same time, it is corrected alongside with changes of designing phase when detailed information account a product occurs (Rachunek kosztów...2003: 375).

The case looks different regarding the so called Japanese conception, where the assumption is that product's life does not end at the time of sale, yet when a final client desists to use a product. Such approach enumerates not only two phases, as it is seen in traditional concept but three phases: designing phase, production phase, post-sell phase. It is reflected in both cost accounting and outcome of LCC causing the total cost are not only manufacturer cost, yet consumer/end-user cost during product life.

During designing phase, $\mathrm{B}+\mathrm{R}$ cost plus project planning cost occur. During production phase, cost of production and sale occur. The cost born by the client/end-user in the postsale phase are usage cost, maintenance cost, reducing product cost (EPA 2008).

Such understood life cycle, as well as based upon cost accounting is consensual with accepted quality philosophy in management processes, especially when taking into consideration small and medium-sized enterprises. Thus, it enables to fully orientate mentioned enterprises upon the market and achieving success in near future.

Mentioning Product Life-cycle Management and taking into consideration the manufacturer's cost and income of sale, one can enumerate the following cycle phases:

a) designing phase - incurred cost upon preparation of product's project, prototype cost: trial series;

b) production phase - cost of product creation: material cost, wages, tools, machines and equipment amortization, incurred cost on maintaining the usage of sold products: spare part cost and wages, marketing and sale cost;

c) post-sale phase - warranty cost, reducing and withdrawal cost reduced at income from redundant tangible assets and accessories (Biernacki 2011: 36-45).

Taking into consideration client's point of view, LCC position costs are as following: purchase cost same as cost of goods sold, maintenance cost (EPA 2008). Such approach enables to evaluate client's satisfaction with the purchase of a new product compared to competitive company's products.

\section{The concept of ELCC cost accounting}

Environmental Life Cycle Costing (ELCC) is on the whole the collation of total cost connected with product's life cycle, which are underwritten with one or more subjects in its life cycle (e.g. supplier, manufacturer, user, consumer, people involved with so called "the end 
of life" phase). Moreover, situation when the mentioned cost needs to relate to real money income may be described as a characteristic one. The main argument of inception and usage of ELCC is that the methods such as LCA are perceived as obstacles for economic growth. It does mainly concern short life cycle of new technologies (Hunkeler, Lichtenvort, Rebitzer 2008: 11).

The main frames of environmental protection cost accounting rely on product's physical life cycle. One should analyse 5 stages that may be expanded and specified if need: research and development, production, usage and maintenance, management during reducing and reprocessing phase (Hunkeler, Lichtenvort, Rebitzer 2008: 11).

Environmental Life Cycle Costing, opposite to traditional LCC, introduces so called environmental cost in the aspect of analysis. They are environment usage economic cost, especially paid for the use of environment, ecological tax, expense of emissions control, expense of ecological products' commercial. In the point of conceptual assumption view of ELCC, cost should be recorded and provided in profit and loss account. Such process generates additional labor input. Its assignation is often merely based on estimation. Moreover, ELCC analyses cost from consumer's side, especially waste disposal expense. In other words, compared to traditional LCC, it dies consider economical cost enlarged by external costs which may potentially arise in future (Hunkeler, Lichtenvort, Rebitzer 2008: 11).

The ELCC is not meant to be treated as an independent technique but to be perceived as an LCA's analysis supplementation. This being said, it should be conducted in the analogical procedure as the technique. LCA is a worldwide and standardized method of estimating the product's influence on the environment and resources usage in its life cycle. It includes the extraction of raw materials, the production, the product usage by the final consumers, recycling, energy recovery and the final disposal of waste. The ELCC should be regarded as supplementation for the ISO 14040 and ISO 14044 life cycle norms. The international ISO norms provide a reliable and well-proven requirements that concern making clear and acceptable calculations (e.g. a carbon footprint) (Kowalski 2007: 160-161).

At present technological development stage in the world, the phases presented above may be essential for the implementation of LCA technique including ELCC. One should take into consideration the fact that specific stages of construction and implementation may change depending on user, consumer, or product. The basic stages are:

1. Defining aim and range of definition.

2. The information gathering.

3. Interpretation and recognition of critical points.

4. The sensitivity analysis.

5. The summary (Kowalski 2007: 160-161).

However, according to M Rosund, the process of making ELCC can be describes as following:

1. Defining a problem.

2. Defining cost elements.

3. The system modelling.

4. Collecting data.

5. Structuring profile cost.

6. Assignment (Rausand 2011).

ELCC based analysis should be performed during second stage of LCA i.e. input data stocktaking (while creating material and energy catalogue one can simultaneously determine the cost) and output data stocktaking (considering the amount of emission and waste 
one can e.g. determine the level of environment usage fee in the case of country's condition) for respective individual processes and for taken functional unit. It causes situation when "inputs \& outputs" are represented in financial measure (Hunkeler, Lichtenvort, Rebitzer 2008: 11).

Considering the ability to determine potential income on the environment both manufacturers and consumers may search goods, products that the least impact the environment (LCA) and have the lowest cost of life cycle (ELCC).

Environmental Life Cycle Costing is defined as a sum of costs that are incurred at the time of designing, building, production, transport, usage of articles until the end stockpiling, market usage and reprocessing. Moreover, while implementing ELCC it is important to determine time horizon (lifetime) of the product in order to perform an analysis in a specific period of time. It should harmonize with determined period of time on the natural environment. Environmental Life Cycle Costing, as it was mentioned above, refers to all costs. They are constituent of system determined by LCA technique. Such understanding causes arising of the following calculation formula:

where:

$$
\text { ELCC }=\mathrm{C}_{\mathrm{ic}}+\mathrm{C}_{\mathrm{in}}+\mathrm{C}_{\mathrm{s}}+\mathrm{C}_{\mathrm{o}}+\mathrm{C}_{\mathrm{m}}+\mathrm{C}_{\mathrm{s}}+\mathrm{C}_{\mathrm{env}}+\mathrm{C}_{\mathrm{d}} \text {, }
$$

$\mathrm{C}_{\mathrm{ic}}$ - introductory investment cost,

$\mathrm{C}_{\mathrm{in}}$ - installation cost,

$\mathrm{C}_{\mathrm{e}}$ - energy cost,

$\mathrm{C}_{0}$ - operation cost,

$\mathrm{C}_{\mathrm{m}}$ - maintenance and repair cost,

$\mathrm{C}_{\mathrm{s}}$ - exploitation interval and production loss cost,

$\mathrm{C}_{\text {env }}$ - environmental cost,

$\mathrm{C}_{\mathrm{d}}$ - disposal, reprocessing, reclaim etc. cost (Kowalski 2007: 174).

The above formula states only output base, which is individually modified by every subject and adjusted to appropriate choice.

In accordance with international research the ELCC should include the investor's risk by using the discount rate presumption. It was determined that there are category items which have their impact on environment. The numbers are: $0,1 \%$ for depletion of resources, 0,01\% for the climate change and 0,001\% for toxicity (Kowalski 2007: 160-161).

ELCC cost differ from LCA method principles because the ELCC includes not only the environment impact but also the costs. In fact, the ELCC and LCA complete one another. However the ELCC is not a method of financial account. It is rather a method of managing costs in sustainable development in order to predict the cost of each product. The LCA is not a method of accountancy but a method required to receive information about a product's full impact on environment, which is crucial in estimating alternatives. The aim and range of ELCC should be determined before research and implementation. It is important to determin the boarders of the system, as well the unit that cost accounting affects. The basic range of activities used in order to define ELCC are:

- total cost determination from subject and consumer side,

- product's evaluation of the competitiveness - determining consumer cost,

- reporting, monitoring and active cost determination inside companies,

- achieving agreement at manager level concerning product portfolio and their corelation with ELCC,

- possible alternatives identification, 
- compromise identification between economical and environmental aspect,

- defining and determining so called corporate social responsibility (CSR) together with social impact assessment,

- identifying potential company and long term cost determination, analyzing potential economical consumer benefits at the EOL (end-of-life) influence on environment and public menace,

- defining relationship among individual criteria (internal cost compared to external cost),

- defining optimal life cycle concerning different changes e.g. material purchase system.

\section{Life cycle costing - supplemental conception}

In practice, a few more "techniques" can be distinguished, they are so called possible application of life cycle costing. They are:

1. Life cycle cost planning (LCCP): identifying the whole cost of production of an item or its composite elements, especially raising and summarizing initial capital expenditures and further costs connected with offered product and formulate it in comparative manner using discount techniques. It is used as well in order to effectively choose among different methods of achieving assumed aim by a company while offering a product. LCCP deals with planning future costs and due to this fact it needs gathering and introducing data from source in order to make external data as real as possible and make them reflect all possible situation. The obtained result should be objective and comprehensive (full), as a result, they would become helpful to project staff and management staff. The technique is based on bringing down to a common denominator both initial and future costs, thus using the technique in decision making process becomes possible (Flanagan 1983: 28-29).

2. Full year effect costs incurred by consumer (FYEC): consists in fulfilling future client's and user's wishes connected with the amount of cost they should bare while stocking up the product. It us used mainly during the projection product phase, when gathering information from future clients concerning the choice of a future product. According to assumptions, the costs in the method are not discounted, nonetheless precursors that used the mentioned method consider the amount of forecasted inflation on their impact. The technique is mainly used in production industry and construction (Flanagan 1983: 28-29).

3. Life cycle cost analysis (LCCA): consists of the analysis of one product's alternative development ways. It is used during project phase and describing product's potential "ways of development and life" concerning cost, performance and repair (Life Cycle... 2002: 2) LCCA is a process of projecting, which aim is controlling the initial and following cost that are bare by the subject in order to offer the type of the product. It may be used in order to define changeability of cost in the whole life of the product, as well as its respective components in the analysis of few planned variants (Life Cycle... 1999: 4). Dahlen and Bolmsjo understand LCCA model in a different manner. They describe it a factor model that is connected with cost analysis of a given product including the whole cycle of hiring employees, i.e. from the beginning of recruitment until terminating them or their retirement. They propose creating 
new cost groups such as cost of absence, rehabilitation or sickness costs (Kowalski 2007: 178).

4. Life cycle cost management (LCCM): defines areas, where current cost are defined by LCCA technique and may be reduced by changing operations management or modifying generative processes. LCCM is used to:

- defining places, where initial arrangement differ from project arrangement,

- why does possible difference between the actual state and arrangement take place and are they significant and can they be eliminated,

- lay down recommendation in order to produce more effectively,

- help in order to maintain product's budget policy,

- advising in tax purposes connected with the product as a whole or component part (Flanagan 1983: 28-29).

LCCM technique concerns designed and manufactured products contrariwise to LCCP, thus it becomes one of the most important elements connected with life cycle costing. (Flanagan 1983: 28-29).

\section{Summary}

Modernly managed companies does not focus only on standard management systems thus does not fulfill expectations of world policy concerning more and more environment protection. Nowadays, it is not sufficient to perceive the product as a as a concrete work, yet it is important to realize all processes that are connected with it. Life Cycle Assessment (LCA) is one of the subsidiary methods to familiarized with production processes that consider the effect on natural environment. Full replenishment of LCA technique takes place when one take into consideration ELCC cost accounting. It provides sustainable connection of both actions in environmental and economical aspect. It may measurably help projecting technological processes, conducting correct management decisions striving toward more rational usage of internal subject stock and reach optimal compromise between environment protection, economic and business aspects. Taking into consideration the world scale, ELCC based information is used in balanced development (consumption and production) based on sustainable decision making process. In practice, allocation of costs to the "environment” account, may be tricky. Many measures taken have multiple functions, and the allocation may be arbitrary. The ELCC debate on allocation and understanding it may be helpful for the managers and eco-sustainability development.

\section{Literatura}

Ansami S., Bell J. (1997), Target Costing. The Next Frontier in Strategie Cost Management, lrvin.

Baussabaine H.A., Kirkham R.J. (2004), Whole Life-cycle Costing. Risk and Risk Responses, Blackwell Publishing Ltd.

Biernacki M. (2011), Rachunek kosztów cyklu życia-ujęcie definicyjne i obszarowe, Prace Naukowe Uniwersytetu Ekonomicznego we Wrocławiu, „Rachunek kosztów I pomiar dokonań” nr 182, red. E. Nowak, M. Nieplowicz, UE, Wrocław.

Ciambrone D.F. (1997), Environmental Life Cycle Analysis, Lewis Publisher, New York.

Dhillon B.S. (1989), Life Cycle Costing. Techniques, Models and Applications, OPA (Amsterdam) B.V. Gordon and Breach Science Publishers.

EPA (2008), What is Life Cycle Management (LCM), [Online] Available from: www.epa.vic.gov.au/Lifecycle/ whatis.asp (10.01.2015). 
Flanagan R. (1983), Life Cycle Costing for Construction, u. a. RICS.

Haworth D. (1975), The Principles of Life-Cycle Costing, „Industrial Forum”.

Hendrikson C.T., Lave L.B., Matthews H.S. (2006), Environmental Life Cycle Assessment of Goods and Services. An Input and Output Approach, RFF Washington.

Informacja zarządcza $w$ procesie formułowania $i$ realizacji strategii firmy - wyzwanie dla polskich przedsiębiorstw (2003), red. G.K. Świderskiej, Difin, Warszawa.

Kowalski Z., Kulczycka J., Góralczyk M. (2007), Ekologiczna ocena cyklu życia procesów wytwórczych (LCA), Wydawnictwo Naukowe PWN, Warszawa.

Life Cycle Cost Analysis Guidelines (2002), Department of Natural Resources, Iowa.

Life Cycle Cost Analysis Handbook (1999), Department of Education \& Early Development, State of Alaska, 1st Edition.

Nowak E., Piechota R., Wierzbiński M. (2004), Rachunek kosztów w zarządzaniu przedsiębiorstwem, PWE, Warszawa.

Rachunek kosztów i rachunkowość zarządcza : najnowsze tendencje, procedury i ich zastosowanie w przedsiębiorstwach (2003), red. Irena Sobańska, C.H. Beck, Warszawa.

Rausand M. (2001), Life Cycle Cost, NTNU, Trondheim.

Woodward D.G. (1997), Life cycle costing - theory, information acquisition and application, "International Journal of Project Management” vol. 15, no. 6.

\section{ŚRODOWISKOWY RACHUNEK KOSZTÓW CYKLU ŻYCIA (ELCC) W ASPEKCIE ZARZĄDZANIA KOSZTAMI PRZEDSIĘBIORSTWA}

Streszczenie: Cel - z metodologicznego punktu widzenia obliczania kosztu cyklu życia (LCC) nie przysparza kłopotów, jeżeli porówna się je do wyliczania tzw. kosztów tradycyjnych. Niniejsza praca ma na celu przedstawienie idei koncepcji środowiskowego rachunku kosztów cyklu życia (ELCC). Koncepcja ta wyraża niejako ciągłe postępy nauki na styku ochrony środowiska oraz rachunkowości. Ekologiczne i zrównoważone metody zarządzania stały się składnikiem obecnych sposobów podejmowania decyzji. Dzięki takiemu podejściu, można stworzyć informacyjną bazę kosztów i przychodów związanych z wpływem danego produktu na środowisko naturalne. Pełna kalkulacja ELCC staje się uzupełnieniem tradycyjnego rozumienia środowiskowego rachunku kosztów cyklu życia. Ponadto całkowity rachunek ELCC jest uzupełnieniem techniki LCA (środowiskowej analizy cyklu życia produktu). Jest ona definiowana zatem jako całkowity koszt cyklu życia produktu wraz z kosztami środowiskowymi. Metodologia badania - w artykule zaprezentowano poszczególne etapy obliczania kosztów środowiskowych w cyklu życiu. Dokonano identyfikacji problemów środowiskowych występujących przy wyodrębnianiu kosztów zewnętrznych i wewnętrznych. Na koniec zaprezentowano dodatkowe techniki wykorzystania tej koncepcji. Wynik - obecnie literatura na ten temat ELCC jest bardzo ograniczona. Przekształca się to w niedostateczną wiedzę dotyczącą szacowania kosztów środowiskowych oraz możliwych dzięki temu korzyści dla środowiska z punktu widzenia podmiotu gospodarczego. Artykuł ten może pomóc menedżerom w kształtowaniu polityki oraz wyliczeń kosztów środowiskowych przez implementację technik ELCC i LCC. Oryginalność/Wartość - niniejszy artykuł przyczynia się do rozwoju świadomości ekologicznej pracowników działów finansowo-księgowych. Oferuje pomoc w rozumieniu zarówno teoretycznym, jak i praktycznym menedżerom różnych szczebli.

Słowa kluczowe: ustalanie kosztów, LCC, LCA, ELCC, zarządzanie środowiskiem

\section{Cytowanie}

Biernacki M. (2015), Environmental Life Cycle Costing (ELCC) in the aspect of cost management in the company, Zeszyty Naukowe Uniwersytetu Szczecińskiego nr 873, „Finanse, Rynki Finansowe, Ubezpieczenia” nr 77, Wydawnictwo Naukowe Uniwersytetu Szczecińskiego, Szczecin, s. 305-312; www.wneiz.pl/frfu. 